\title{
A PRIMAZIA DOS CIENTISTAS NATURAIS NA CONSTRUÇÃO DA AGENDA AMBIENTAL CONTEMPORÂNEA*
}

\section{José Augusto Drummond}

\section{Introdução}

Este texto tem o objetivo de mostrar que a agenda ambiental contemporânea foi construída quase integralmente por cientistas filiados às ciências naturais ou tecnológicas. Considero, por conseqüência, que os cientistas sociais chegaram a ela de forma retardatária e, por vezes, parcialmente equivocada. Este texto foi motivado por uma antiga constatação de ordem pessoal, qual

* Versão revista do texto "Os cientistas sociais na construção da agenda ambiental contemporânea: uma participação retardatária e parcialmente equivocada”, apresentado no XXVIII Encontro Anual da Anpocs (Caxambu, outubro de 2004). Agradeço a José Luiz de Andrade Franco pela leitura crítica a uma versão anterior deste texto.

Artigo recebido em janeiro/2005

Aprovado em abril/2006 seja, a de que os cientistas sociais em geral resistem à primazia dos cientistas naturais na questão ambiental, e por isso se permitem ignorar suas contribuições, ou - o que dá no mesmo - criticálas de forma errada e empobrecedora.

Não sustento que quem "chegou primeiro" tenha toda a virtude, nem que quem "chegou depois" careça de qualquer virtude, pois não se trata de uma corrida, e sim de um processo de construção do conhecimento. A "lição" mais relevante a tirar desse fato é prosaica: os cientistas sociais interessados em estudar a questão ambiental têm e continuarão a ter muito a aprender com os cientistas naturais. Embora o inverso também seja verdadeiro, em muitos casos foram os próprios cientistas sociais que, infelizmente, contribuíram para enquadrar os pioneiros da questão ambiental em rótulos desqualificantes e equivocados - tais como serem "insensíveis aos problemas sociais", "neomalthusianos", "naturalistas", "preocupados apenas com plantas e animais" e assim por diante. 
Este texto discute primeiro o conceito de "desenvolvimento sustentável", importante marco estabelecido há cerca de quinze anos e que baliza o pensamento de quase todos os cientistas sociais que hoje se ocupam de temas ambientais. Segundo, analisa a resistência generalizada dos cientistas sociais ao estudo das questões ambientais emergentes. Em seguida, com a finalidade de contextualizar a "linha de ascendência" do conceito de desenvolvimento sustentável, focaliza as contribuições mais antigas de cientistas "ícones" da descoberta ou formulação das grandes questões ambientais dos últimos setenta anos -Paul Sears, Aldo Leopold, Rachel Carson, Paul Ehrlich, Donella Meadows, Garrett Hardin e James Lovelock. Esses autores são abordados em separado, de acordo com tópicos que descrevem a contribuição principal de cada um, mas buscando também identificar algumas linhas de continuidade ou, ao menos, de contato entre eles.

Esses autores - ao contrário do que se divulga persistentemente entre os cientistas sociais - mostraram, sim, sensibilidade quanto às questões humanas ou sociais, entendidas como conexas aos - e causadas ou causadoras dos - problemas ambientais ou naturais, mesmo sendo todos formados nas ciências naturais ou da tecnologia - biologia, ecologia, química, física, medicina etc. Argumento ao longo deste texto que os cientistas sociais ainda têm muito a aprender com esses "pioneiros", caso se disponham a conhecer em fonte direta suas contribuições. Isso servirá para melhor entender e aplicar, entre outras coisas, o paradigma mais conhecido e consensual do desenvolvimento sustentável.

\section{O conceito de desenvolvimento sustentável}

O conceito de desenvolvimento sustentável e o paradigma da sustentabilidade foram amplamente veiculados pelo documento intitulado Our common future, escrito em meados da década de 1980 pela Comissão Mundial de Meio Ambiente e Desenvolvimento, da ONU, chefiada por Gro Brundtland. No Brasil, esse relatório (por vezes conhecido como "Relatório Brundtland") foi publicado em 1987 com o título Nosso futuro comum (CMMAD, 1987).
Publicado em muitos idiomas, esse texto teve larga divulgação e aceitação em muitos fóruns científicos, governamentais, intergovernamentais, nãogovernamentais e empresariais, não obstante as inevitáveis polêmicas em torno de um conceito tão complexo quanto o de desenvolvimento sustentável. Considero que o principal motivo para a sua grande divulgação e aceitação foi o equilíbrio alcançado no equacionamento conjunto dos problemas propriamente ecológicos ou biofísicos do mundo natural, de um lado, e das questões sociais correlatas, de outro. Esta é, de fato, uma forte virtude presente no conceito. Quase duas décadas depois de sua formulação original, o conceito e o paradigma da sustentabilidade continuam a ser amplamente adotados como componentes de um modelo interpretativo a um só tempo abrangente e sintético, o que mostra que há uma tendência no sentido de ganhar cada vez mais espaço.

Produzido pela chamada Comissão Brundtland, tal relatório formulou sinteticamente o conceito de desenvolvimento sustentável como "aquele desenvolvimento que atende às necessidades do presente sem comprometer as possibilidades de as gerações futuras atenderem às suas próprias". Essa formulação é inovadora sob diversos aspectos, embora não o seja em outros. O componente da "solidariedade intrageracional", por exemplo, é mais comumente conhecida como eqüidade. No entanto, ele faz parte de muitos ideais, ideologias e conceitos mais antigos e bastante disseminados. Já o preceito de visar ao bemestar das gerações futuras, além de também não ser original, é apresentado pela CMMAD sem qualquer fundamentação capaz de resgatá-lo de meras advinhações bem-intencionadas sobre o que seria bom para as gerações futuras - no limite, ele se resume a conselhos genéricos quanto a atitudes de prudência.

De toda forma, reunir sustentabilidade, eqüidade e preocupação com as gerações futuras é suficiente para garantir a originalidade e a relevância do conceito. O que interessa destacar aqui é que a idéia de desenvolvimento sustentável buscou explicitamente atingir um equilíbrio entre uma visão "naturalista" e uma visão "social" da moderna questão ambiental, conforme ela foi construída nas décadas anteriores. O Relatório Brundtland conectou, com sucesso, dois conjuntos de problemas: (1) os propriamente ecológicos do mundo 
natural, decorrentes das ações humanas (uso ou escassez de recursos naturais, extinção de espécies, poluição, contaminação, aquecimento global, desertificação etc.) e (2) os propriamente sociais (doença, fome, pobreza, exclusão etc.).

No entanto, é necessário fazer uma grande ressalva. Rigorosamente, a dimensão ecológica do conceito de desenvolvimento sustentável também carece de originalidade, pois nasce de um conceito estabelecido há décadas na ciência da biologia - "capacidade de carga" (carrying capacity), ou "capacidade de suporte". A "novidade" é a sua aplicação sistemática para o estudo de sociedades humanas, o que é fruto do trabalho de cientistas naturais interessados nas questões ambientais.

"Capacidade de carga" é definida em obras de referência de várias formas parecidas. Afirma o A dictionary of ecology da Oxford University Press, por exemplo, que se trata da "população máxima de um determinado organismo que pode ser sustentado por um ambiente particular" (Allaby, 1998, p. 73). "Capacidade de suporte" é definida por outra fonte de referência como "a população limite de uma espécie num sistema natural" ou a "densidade populacional que pode ser sustentada por recursos limitados" (Silva et al., 2002, p. 40). Munidos desse conceito, biólogos e ecólogos criaram e aplicam há muitas décadas métodos para descobrir quantas plantas ou animais de certas espécies podem ser sustentados "indefinidamente" por um ecossistema, ou seja, sem causar um colapso nele ou sem eles mesmos entrarem em colapso a ele. Isso depende de diversas variáveis, como a posição da espécie estudada na cadeia trófica, suas necessidades de alimento e abrigo, sua taxa de reprodução e a competição que ela sofre de outras espécies com que disputa alimento e abrigo. Esses estudos buscam resolver uma fração cujo numerador é o número de indivíduos de uma espécie que vive numa área e cujo denominador é dado pela quantidade de recursos da mesma área usados "indefinidamente" pela espécie, o que leva a um cifra cuja unidade pode ser, por exemplo, o número de indivíduos por hectare.

Aplicado às sociedades humanas, o conceito de capacidade de carga levou diversos cientistas naturais a enxergarem os limites relativos ao que a espécie humana poderia retirar do planeta como um todo para reproduzir sua existência sem pre- judicar os ecossistemas. Isso direcionou a atenção de parcelas crescentes de cientistas, governantes e cidadãos para uma grande variedade de questões ambientais, associadas a usos e abusos que as sociedades humanas fazem dos recursos naturais finitos do planeta.

Com efeito, tal conceito, quando aplicado aos humanos, diz respeito, antes de tudo, àquela fração já mencionada, em que:

1. O numerador é o número de seres bumanos que consomem os recursos escassos (ou seja, como sources, ou fontes) e geram resíduos que têm lugares escassos (ou seja, como sinks, ou pias) ou para serem "jogados fora".

2. O denominador é a soma de duas parcelas: (1) os recursos naturais finitos e/ou escassos consumidos pelos bumanos + (2) a capacidade limitada dos ecossistemas naturais de assimilar as pressões e os resíduos gerados pelo modo de vida bumano (o que não deixa de ser uma outra forma de escassez) - ou seja, souces + sinks.

3. O resultado da fração é uma cifra que indica quantas pessoas podem ser sustentadas por uma unidade do recurso (em volume, em peso, em área etc.), quer como source, como sink, quer como ambos.

O relatório da Comissão Brundtland veio na esteira de pelo menos quarenta anos de preocupações ecológicas-ambientais entre cientistas naturais e de aplicação do conceito de capacidade de carga ao que hoje chamamos de questões ambientais. Quem pensou sobre essas questões, pioneiramente, foram os cientistas naturais que, trabalhando individualmente ou em grupos, redes e comissões, produziram estudos tão importantes e influentes, guardadas as especificidades de época, quanto o relatório da Comissão Brundtland, embora em geral tenham tido uma recepção mais polêmica.

Sem que ninguém pudesse prever, esses estudos cumpriram, no entanto, a difícil tarefa de fundar ou codificar as grandes questões ambientais reconhecidas e debatidas contemporaneamente. O texto da Comissão nasceu, portanto, num território já aberto por esses pioneiros - território não apenas temático, mas também conceitual. 
Sustento, portanto, que o conceito de desenvolvimento sustentável é, por assim dizer, um "filho" sociológico do conceito biológico de capacidade de carga.

Cabe ressaltar que a grande maioria dos cientistas sociais que hoje se interessa pelas questões ambientais usou como "porta de entrada" o conceito mais recente de desenvolvimento sustentável. Mas, infelizmente, poucos conhecem o trabalho daqueles cientistas naturais pioneiros, e alguns ainda proclamam que é preciso "derrubar a ditadura dos biólogos" - exortação acompanhada às vezes por declarações "ousadas" a favor da interdisciplinaridade.

Não há dúvida de que os textos fundadores da questão ambiental foram quase todos escritos por cientistas naturais ou da área tecnológica - biólogos, ecólogos, químicos, analistas de sistemas, físicos etc. Foram eles que identificaram, publicaram trabalhos a respeito e levaram para a agenda pública as grandes questões ambientais modernas esgotamento e poluição de recursos naturais (solos, água, minérios, atmosfera), extinção de espécies e perda da biodiversidade, estrangulamentos e externalidades da produção de energia, desertificação, efeito estufa, destruição da camada de ozônio, destinação inadequada de resíduos, reciclagem e reuso, entre outras - de que se ocupam hoje novas gerações de cientistas naturais e sociais, além de cidadãos, organizações civis, governantes e empresários. ${ }^{1}$ Para quem conhece em primeira mão a literatura produzida por aqueles autores e, de início, sua limitada receptividade entre cientistas sociais do mundo inteiro, é patente a constatação de que muitos cientistas sociais persistem como retardatários na questão ambiental.

\section{A resistência dos sociólogos à questão ambiental - fundamentos}

O marco do desenvolvimento sustentável evoluiu, como vimos, na esteira de um prolongado debate, explicitado a partir da década de 1950, dentro de um novo campo de preocupações que sequer angariara para si a chancela de "científica" ou o nome de "ambiental". É certo afirmar que esse campo foi fundado com um viés que hoje se chama pejorativamente de "naturalista", refletindo a formação científica daqueles pioneiros. Não obstante, seria errôneo afirmar que aqueles cientistas não tinham preocupações com a sociedade humana e que foi preciso a intervenção "salvadora" de cientistas sociais para que emergissem tais preocupações.

Vale dizer, em primeiro lugar, que, ao "inventarem" a questão ambiental moderna, aqueles cientistas pagaram preços altos, uma vez que entraram em confronto direto com interesses poderosos. Refiro-me (1) ao mainstream do pensamento científico de muitas disciplinas estabelecidas e poderosas, (2) a órgãos governamentais, (3) a grupos empresariais, e (4) a agências financiadoras de pesquisas. Esses grupos sequer admitiam a existência dos problemas apontados e/ou não admitiam que suas atividades fossem de alguma forma limitadas pelo reconhecimento de tais problemas. Estudar a questão ambiental nas décadas de 1950 e 1960 estava, pois, ainda longe de ser uma opção promissora para consolidar ou iniciar carreiras científicas bem-sucedidas. Era muito mais uma maneira de abalar o status quo científico-tecnológico, o que nunca se faz sem reações de grupos poderosos e sem implicações sociais.

Em segundo lugar, é preciso ter em mente que, nessa fase e mesmo muitos anos depois, os cientistas sociais foram quase sempre indiferentes à matéria, mesmo nos países desenvolvidos. Dunlap e Catton (1979), por exemplo, mostram que a disciplina da sociologia como um todo (representada principalmente, mas não unicamente, pela produção em língua inglesa, original ou traduzida) deu uma atenção "tardia" às questões que hoje chamamos de ambientais. Além de tardia, foi também limitada, pois havia ainda uma questão de fundo, metodológica ou filosófica, qual seja, a recusa implícita - e às vezes explícita - dos cientistas sociais de levar em conta fatores naturais e biofísicos como variáveis legítimas da análise sociológica. Ou seja, os sociólogos entraram na nascente era ambiental portando o que considero um sério handicap - o princípio durkheimiano de que só é possível explicar o social pelo social. Perderam, assim, a chance de ter um papel significativo na emergência dos estudos e das pesquisas sobre as questões ambientais, em que o social era definido, desafiado, limitado ou condicionado pelo natural. 
Dunlap e Catton argumentam que sociólogos clássicos como Durkheim, Weber e Marx, apesar de admirarem o triunfo do evolucionismo biológico darwinista, construíram modelos explicativos da sociedade tacitamente concebidos para diferir do modelo biológico. Fred Buttel (1986) afirma que o estilo de trabalho eclético desses e de outros clássicos da sociologia permite que se encontre em seus trabalhos alguma atenção a fatores naturais - como espaço, densidade populacional e escassez de recursos, em Durkheim; complexas tecnologias agrícolas e industriais, em Weber; e a ciência dos solos e a agronomia em Marx. No entanto, a emergência, no final do século XIX e início do século XX, do "darwinismo social" de Spencer e de teorias racistas ou de "espaço vital" (como a de Ratzel), inclusive com implicações belicistas e genocidas, fez com que os cientistas sociais seguidores dos clássicos dispensassem as variáveis naturais, que já eram empregadas de maneira tão frágil, como instrumentos da explicação sociológica.

Dunlap e Catton sustentam também que, em meados do século XX, quando emergia a questão ambiental, os sociólogos estavam imersos num "paradigma de imunidade humana" (buman exemptionalism paradigm), que se baseava na imunidade das sociedades humanas em relação às variáveis naturais. Explicar o social pelo social era nesse momento um traço mais do que cinqüentenário das ciências sociais. Duas ou três gerações de sociólogos tinham sido treinadas para estudar os processos e os eventos sociais e culturais como fenômenos imunes ao alcance das variáveis naturais. Foi isso que prevaleceu na disciplina.

Esses autores constatam, ainda, que essa situação mudou mais recentemente, com a formação de um campo de "sociologia ambiental", mas insistem no fato de que isso só ocorreu devido a pressões "externas", na forma de questões ambientais cada vez mais visíveis, mais graves e mais amplas, e que resistiam a explicações puramente sociológicas. Lembram que essas questões foram identificadas e estudadas por cientistas naturais e da área de tecnologia, cujo trabalho propriamente científico (em alguns casos, eles se tornaram também ativistas ambientais, empenhando-se na divulgação dessas questões) deu margem à emergência de uma consciência ambientalista entre parcelas crescentes da população. Em outras palavras, a emergência de um "novo paradigma ambiental" entre os sociólogos não decorreu de uma mudança endógena no âmbito da perspectiva e da metodologia da disciplina. Escrevendo em 1986, Buttel afirmava que a "sociologia ambiental" de língua inglesa, mesmo depois de vinte anos de produção e ganhando legitimidade crescente nos meios sociológicos, não conseguira dar uma nova forma ou direção à sociologia praticada nos Estados Unidos. ${ }^{2}$

Destaque-se ainda que, para a maioria dos sociólogos, mesmo entre os que ingressaram na questão ambiental pelo portal mais recente da sustentabilidade, continuou a prevalecer o "paradigma da imunidade humana". Essa é, a meu ver, a mais grave limitação à eficácia das intervenções de cientistas sociais no estudo das questões ambientais.

\section{As ciências naturais e a "invenção" das grandes questões ambientais}

A seguir, examino as contribuições de sete cientistas naturais que, a partir da década de 1930, "criaram" ou contribuíram para disseminar os principais problemas que hoje classificamos consensualmente como "ambientais". Esse tipo de problema é tão facilmente identificado hoje graças ao pioneirismo, à competência, à ousadia e, por vezes, à capacidade "cidadã" desses cientistas de lutar e divulgar suas descobertas fora do meio científico, remando contra "marés" pouco propícias, como, por exemplo, a generalizada indiferença e eventual hostilidade que suas contribuições mereceram de cientistas sociais.

Abordarei esses autores - reitero: Paul Sears, Aldo Leopold, Rachel Carson, Paul Ehrlich, Donella Meadows, Garrett Hardin e James Loveloc - seguindo um roteiro de tópicos (parcialmente em ordem cronológica) de que me vali para enquadrar suas contribuições mais expressivas. ${ }^{3}$

\section{A desertificação esteriliza projetos bumanos ${ }^{4}$}

Focalizo primeiramente uma obra editada em 1935, cerca de vinte anos antes do início da 
disseminação da preocupacão ambiental moderna em meados da década de 1950. Foi escrita por Paul Bigelow Sears (1891-1990), botânico norteamericano que fez parte de um grupo de cientistas naturais advindos de diferentes países, dedicados a estudar o fenômeno da desertificação em escala planetária. Este grupo formou duradouras linhas e redes de pesquisa e de monitoramento que se tornaram a base de políticas públicas e que atuam de maneira contínua há sete décadas, às vezes com apoio de organizações intergovernamentais, como, por exemplo, a FAO - United Nations Food and Agriculture Organization. Entre outras coisas, essas linhas e redes fizeram dos desertos ecossistemas mais conhecidos cientificamente do que as florestas tropicais úmidas, valorizadas apenas mais recentemente. O livro mais famoso de Sears, Deserts on the march (1988 [1935]), foi lançado quando os Estados Unidos vivenciavam, em seus desertos ou quase-desertos, um dos maiores desastres ambientais registrados no mundo moderno - as tempestades de vento e areia que ganharam o apelido de Dust Bowl, amplas e graves conseqüências para os habitantes da região dos Great Plains, limítrofe a vários desertos, a oeste e sudoeste, o que despertou temores quanto à expansão dos mesmos.

Conhecido livro de divulgação científica, Deserts on the march focaliza o rumoroso Dust Bowl e deve parte de sua popularidade ao medo "doméstico" dos norte-americanos ante o desastre ambiental e a perspectiva de ampliação dos já extensos desertos do país. No entanto, Sears trata dos desertos de uma maneira em geral, em outros continentes e de períodos da história antiga e contemporânea. Narra dezenas de processos e episódios em que sociedades diversas foram algozes de si mesmas, ao praticar extrativismo, agricultura, pecuária, corte de árvores e manipulações da água que ajudaram a formar ou a ampliar desertos estéreis, incapazes de sustentar as atividades humanas.

Apesar de se basear principalmente em conceitos e análises oriundos da geologia, da climatologia e da botânica, áreas nas quais desenvolvia trabalhos estritamente "naturalistas", sobre os quais acumulou prêmios, homenagens e honrarias, Sears notabilizou-se precisamente por documentar como muitos povos - denominados por ele "fabricantes de desertos" - cavaram o seu próprio abismo, repetindo erros e recusando-se a respeitar os limites que a natureza impõe às sociedades humanas. Ele não lamentava "naturalisticamente" a erosão dos solos ou o secamento dos rios, o sumiço da flora ou a morte da fauna - o que lhe interessava era mostrar os efeitos desastrosos da desertificação sobre homens e mulheres de muitos lugares e diferentes épocas. Vale lembrar que muitos desertos consolidados do mundo continuam a se expandir hoje em dia, mesmo depois de décadas da atenção e da intervenção fundadas por Sears e contemporâneos, e que há muitos outros lugares - inclusive no Brasil - sujeitos a processos menos adiantados de desertificação.

"Não é apenas o solo, nem a planta, nem o animal, nem o clima que precisamos conhecer melhor, mas principalmente o próprio homem"; "Não se consegue conquistar a natureza, a não ser nos seus próprios termos" (Idem, pp. xiv, 3) são frases lapidares que ilustram de maneira precisa o ponto que desejo destacar, a saber, o fato de esses cientistas naturais terem usado seus conhecimentos sobre a natureza e seus processos para diagnosticar problemas que estavam longe de ser apenas naturais. Em outras palavras, eles tentaram explicar como esses fenômenos eram ligados a atividades humanas e como interferiam no bem-estar e na própria sobrevivência dos humanos. Interessavamse em discutir como tais problemas poderiam ser evitados e como suas conseqüências poderiam ser mitigadas ou revertidas pela ação coletiva de sociedades e governos. Nem sempre foram os analistas mais bem preparados ou mais competentes das causas e das implicações sociais, econômicas e políticas desses problemas naturais, e nem sempre propuseram ações viáveis. No entanto, foram eles que trouxeram tais problemas para a agenda pública, abrindo espaço para que cientistas sociais, entre outros grupos, pudessem examiná-los com o instrumental próprio de suas ciências e propusessem ações viáveis, embora isso, infelizmente, quase sempre tenha demorado décadas para ocorrer.

\section{A ética da terra - ou a questão do comportamento bumano}

Aldo Leopold (1887-1948), norte-americano, formou-se em engenharia florestal, mas sua fama como cientista se deve principalmente ao seu 
papel de fundador de uma nova disciplina científica, denominada "manejo de vida silvestre" (wildlife management). Fez carreira como funcionário do US Forest Service e, depois, como diretor associado do importante Laboratório de Produtos Florestais da University of Wisconsin. Nessa mesma universidade, fundou uma cadeira pioneira dessa disciplina, por meio da qual ajudou a formar centenas de estudiosos e gerentes de áreas preservadas, especializados em reconhecer e neutralizar os percalços que a vida selvagem e seus habitats sofrem com a expansão das atividades humanas, dentro e fora de unidades de conservação. O departamento e o curso de pós-graduação de manejo de vida silvestre da University of Wisconsin existem até hoje e continuam na vanguarda da área.

Leopold foi também um ativista ambiental. Em 1924, ajudou a fundar a Wilderness Society, importante organização civil ambientalista que se dedica principalmente à proteção de animais selvagens e de seus habitats, apoiando a criação e a administração de UCs, fazendo lobby a favor de leis protetoras da fauna e da flora e engajando-se em campanhas educacionais e protetoras. Além disso comprou uma fazenda falida em Wisconsin e gastou grande parte do seu tempo livre tentando restaurar o ecossistema nativo (pradarias de gramas altas), trabalho que se conectou com o de outros grupos de cientistas que ajudaram a University of Wisconsin a emergir na vanguarda da ainda jovem ciência de restauração de ecossistemas.

Como se pode observar, Leopold tinha as mãos repletas de tarefas "naturalistas", aparentemente desconectadas de problemas "sociais". Poderia se ocupar delas por toda a vida, se quisesse. Porém, poucos meses antes de morrer acidentalmente combatendo um incêndio nas proximidades de sua fazenda, entregou a uma editora os originais do que viria a ser um dos textos mais influentes para a formação da moderna consciência ambientalista - A Sand County almanac (Leopold, 1984 [1949]). O livro reuniu escritos inéditos e alguns dos seus muitos textos publicados em diversas fases de sua vida de profissional e ativista.

As primeiras duas partes do livro consistem de relatos, em forma de vinhetas e crônicas, sobre mudanças na natureza que ocorriam em sua fazenda e vizinhança, causadas tanto pela sucessão de estações como por atividades produtivas das fazendas. Aparentemente simplórios e "naturalistas", esses textos breves de história natural contêm, no entanto, ricas observações registradas pelo seu olho bem treinado para distinguir mudanças naturais das mudanças de origem antrópica - uma distinção nada banal para quem lida com a questão ambiental. A terceira parte reúne textos publicados anteriormente sobre a paisagem rural-selvagem de várias regiões dos Estados Unidos, iniciativas de proteção de paisagens e espécies etc. Tudo "naturalista" demais, talvez, para alguns cientistas sociais. Na quarta parte, porém, Leopold dá um salto e adentra o terreno da filosofia, dos valores e do comportamento humano em relação à natureza. Ele trata do conceito de land ethic, expressão que se pode traduzir como "ética da terra" ou "ética ambiental". Esse seria o tipo de ética que a sociedade deveria assumir para ter um comportamento conseqüente em relação ao ambiente - uma ética a ser praticada não apenas entre seres humanos, mas também entre esses e os demais membros da "comunidade biótica". Leopold destacava a expansão da ética na história das sociedades ocidentais, de forma a proteger círculos cada vez maiores de pessoas - mulheres, pobres, escravos e estrangeiros - das arbitrariedades e da violência de seus semelhantes. Fazia um paralelo disso com a nova expansão ética que teria que ocorrer nas relações entre os homens e a terra. Assim como não mais se admite nas sociedades modernas que se cometam arbitrariedades contra seres humanos, dizia Leopold que a terra se se deseja que ela seja protegida- não mais poderia ficar a mercê da arbitrariedade dos comportamentos humanos. A relação puramente econômica dos homens com a terra, segundo ele, criaria apenas privilégios unilaterais, e não obrigações e restrições mútuas, levando a um tratamento predatório sistemático em relação a ela. Ou seja, ele propunha uma relação estreita entre as formas com que os homens se tratam e a maneira que eles interferem nos demais componentes do mundo natural.

Leopold via no ainda nascente movimento ambiental uma nova força social capaz de, finalmente, incluir a terra no rol dos entes eticamente protegidos. A ética da terra não poria fim ao inevitável uso humano dos componentes da nature$\mathrm{za}$, mas "afirmaria o seu [da natureza] direito à 
existência contínua", até mesmo no que concerne o estado natural ou intocado, em alguns casos. O autor afirmava que a conservação baseada apenas numa ética econômica ou utilitarista era insuficiente, pois deixaria de fora a maior parte da flora e da fauna (por serem "inúteis"), as terras nãoagricultáveis, os minérios sem uso, as paisagens "feias" e assim por diante.

A ética proposta por ele abarcaria a sociedade humana e todos os componentes da natureza numa única e abrangente "comunidade biótica". Isso é outra maneira de dizer que a natureza e seus componentes não precisam ser úteis para os humanos para merecerem proteção ou uso cuidadoso eles têm um valor intrínseco, independente de e irredutível à sua utilidade. Vale lembrar que esse é o núcleo conceitual de uma sofisticada e radical corrente ambientalista contemporânea, desenvolvida décadas depois, principalmente por filósofos e denominada "ecologia profunda" (deep ecology).

Leopold sabia que, ao propor uma postura como essa, estava exigindo muito... Coerentemente, considerava que a conservação da natureza baseada nessa ética não seria tarefa a ser desempenhada por governos vigilantes e repressivos, dedicados a espionar minuciosamente os cidadãos; seria tarefa de cidadãos virtuosos, educados, conscientizados de que a ética da terra seria a melhor para todos. A conservação, nesses termos, não consistia um empreendimento repressivo, embora fossem necessárias leis severas. O autor reconhecia que se tratava de uma missão para gerações, no sentido de convencer e educar a população em geral, trabalho que certamente seria conduzido por uma minoria ativa e desinteressada, visando à mudança de comportamentos profundamente enraizados. Somente cidadãos, fazendeiros e industriais convencidos da validade da ética da terra seriam capazes de tratar a natureza de forma não-destrutiva. Pode-se dizer que Leopold era um otimista, pois via na história filosófica humana uma passagem profícua da barbárie, em que os homens se encontravam num estado hipotético de natureza, à formalização de uma ética primeiramente limitada a alguns círculos sociais e, depois, inclusiva de todos os seres humanos. Estender tal ética aos componentes da natureza seria um grande passo, mas nada tão ou mais difícil do que a humanidade já conseguira.
Não há dúvida, portanto, de que essa influente reflexão desse cientista natural sobre as relações humanas e entre os humanos e a natureza nada tem de "naturalista".

\section{Poluição e contaminação - de passarinhos, peixes e pessoas}

Depois da década de 1950, na esteira de Sears, Leopold e outros cientistas naturais, os biólogos lideraram a formulação das grandes questões ambientais do nosso tempo e o seu enquadramento simultâneo como questões sociais. Muitos autores que se dedicam a estudar as origens do movimento ambiental contemporâneo consideram que o marco fundador foi o lançamento, em 1962, do livro Silent spring (1962), da bióloga norte-americana Rachel Carson (19071964). O livro causou forte e duradoura comoção pública nos Estados Unidos e em outros países, influenciou carreiras científicas, criou linhas de pesquisa e desdobrou-se em regulamentos e leis que tiraram do mercado produtos modernos e de alto valor agregado. É comum cientistas e ativistas ambientais veteranos, de muitas partes do mundo, afirmarem hoje em dia que se "converteram" à questão ambiental lendo esse livro e testemunhando sua repercussão.

Ao contrário do que geralmente se pensa, no entanto, Silent Spring foi para Carson um livro de maturidade e quase de ruptura. Antes de 1962, ela publicara ao menos outros três livros (ver, entre eles, Carson, 1941; 1950), cujas narrativas e foco eram inteiramente diferentes de Silent Spring. Tratava-se de textos que a inseriam no que hoje se chama - quase sempre pejorativamente - de campo "naturalista". Ela praticava uma espécie de história natural dos mares, oceanos e litorais, e dos seres vivos que neles habitavam, dando atenção apenas secundária às sociedades humanas. Publicou em editoras e revistas de prestígio, lecionou em universidades renomadas, teve bolsas de pesquisa, ganhou prêmios literários e foi bastante homenageada. Trabalhou como bióloga (e depois como editora) de um órgão federal que mais tarde assumiria grande importância nas políticas ambientais dos Estados Unidos (US Fish and Wildlife Service). 
Silent Spring é uma obra bem diferente. Tratase de um livro de denúncia. Carson narra as sombrias descobertas e constatações (suas e de outros cientistas naturais) a respeito das conseqüências diretas e indiretas, na natureza e na sociedade, do uso indiscriminado dos modernos pesticidas, herbicidas e fungicidas agrícolas (e substâncias associadas). O título refere-se, um tanto poeticamente, ao fato de que certas espécies de pássaros dos Estados Unidos, antes com populações muito numerosas, tornaram-se raras, "silenciando" as primaveras antes marcadas pelos seus cantos. Suas pesquisas mostraram que essas aves estavam sendo eliminadas pelos efeitos diretos e indiretos daquelas substâncias, em alguns casos aplicados em áreas agrícolas situadas a centenas de quilômetros dos litorais e dos estuários atlânticos nos quais a autora realizava suas pesquisas.

Não se trata, porém, de um livro lírico sobre passarinhos, mas um relatório sério, áspero e perturbador sobre os riscos e as calamidades que a sociedade mais próspera do planeta estava introduzindo voluntária e entusiasticamente no ambiente natural do seu próprio território. Contestou, com sólida base científica, a moderna, dinâmica e lucrativa prática agrícola - propiciada por conglomerados e produtos industriais de prestígio inabalado que criava efeitos deletérios de longo prazo sobre o ambiente natural e as sociedades humanas, uma vez que essas também eram altamente suscetíveis aos efeitos negativos dos agrotóxicos. Assuntos "desagradáveis" como câncer, mutações genéticas, lesões nervosas, intoxicações, defeitos congênitos, envenenamentos - tudo isso em seres humanos - abundam nos concisos e bem organizados parágrafos de Carson. Ela por certo abordava pássaros raros e peixes envenenados, mas estava preocupada, antes de tudo, com a saúde e o bem-estar dos humanos.

Silent Spring desencadeou um movimento social que, entre outras coisas, levou ao banimento do DDT e ao controle sobre outros agrotóxicos e substâncias tóxicas nos Estados Unidos, um dos primeiros casos de controle público sobre atividades produtivas modernas. Embora alguns cientistas sociais equivocados ainda hoje pensem que Carson se preocupava apenas com passarinhos, já em 1962 os executivos de empresas produtoras de pesticidas, o lobby dos fazendeiros modernizados e os dirigentes de alguns órgãos públicos sabiam muito bem que ela estava desafiando o seu poderio econômico. Tentaram, sem sucesso, desqualificá-la como cientista e estigmatizá-la como alarmista, mas foram derrotados com o banimento da produção e do uso nos Estados Unidos do DDT, símbolo maior da primeira geração de pesticidas sintéticos. Mesmo assim, esse produto continuou a ser fabricado e usado em outras regiões do mundo que desprezaram as constatações de Carson e de outros cientistas que, desde então, monitoram os efeitos negativos de sucessivas gerações de pesticidas sintéticos. Graças a ela, no entanto, o tema dos efeitos potencialmente perigosos de pesticidas e de muitas outras substâncias sintéticas foi inscrito permanentemente na agenda ambiental, quer nas ciências, nas políticas públicas, quer no campo do ativismo ambiental. ${ }^{5}$

\section{Crescimento populacional - os humanos sobrelotam o planeta}

A questão do crescimento populacional também fez parte da "invenção" da questão ambiental contemporânea. O melhor registro disso são os escritos de Paul R. Ehrlich (1932), biólogo norteamericano. Ele fez carreira na University de Stanford (Califórnia, Estados Unidos) como professor de estudos populacionais (trata-se de populações de plantas e animais). Ehrlich iniciou sua carreira na década de 1950, pesquisando casualmente um assunto que preocupava bastante Rachel Carson no final de sua carreira - o desenvolvimento de populações de insetos (considerados "pragas") resistentes aos pesticidas, por via da seleção genética. Ehrlich tornou-se um perito em populações, co-evolução, dinâmicas reprodutivas de animais e biologia da conservação, além de ser um importante divulgador do darwinismo e do conceito de serviços ecossistêmicos. São assuntos mais do que suficientes para compor uma bem-sucedida carreira científica na disciplina da biologia. Ehrlich poderia ter prosseguido estudando exclusivamente a dinâmica reprodutiva das populações de simplórias e incontroversas borboletas checkerspots residentes nas vizinhanças do campus de Stanford. No entanto, a partir de 1968, ele se deteve no estudo da reprodução dos seres humanos. Publicou 
um livro que se tornaria um clássico da questão ambiental - The population bomb (Ehrlich, 1986 [1968]), um dos grandes best-sellers mundiais de sua época. Com ele, Ehrlich passou a ser porta-voz e protagonista do movimento ambientalista, já que o livro é uma conclamação à ação. A "bomba populacional" de que ele tratou não era a das inofensivas moscas Drosophila (cuja resistência ao DDT ele estudara no início da sua carreira), mas a de seres humanos. Como vemos, era mais um biólogo a tratar de uma questão a um só tempo social ambiental, sob a ótica da sustentabilidade.

Ele deve ter sido o primeiro autor bastante difundido que transferiu explicitamente para o estudo das sociedades humanas o conceito de capacidade de carga. Aplicou esse conceito em escala planetária e chegou a conclusões alarmistas - quando não catastrofistas - de crises e mesmo de colapsos iminentes na produção de alimentos e na oferta de matérias primas em geral. Apesar de seu tom sombrio e alarmista (aspecto aliás muito comum em várias correntes da literatura ambientalista, até hoje) e de alguns cálculos equivocados, trata-se de um estudo do que hoje chamamos de "sustentabilidade ecológica" da espécie humana como um todo, tendo como base os recursos naturais do planeta.

A recepção à obra foi polêmica, originando debates sérios e duradouros. Os críticos logo compararam Ehrlich a Thomas Malthus (1766-1844), economista político britânico que, no século XVIII, propôs a existência de uma relação direta entre a fome e o crescimento acelerado da população carente na Grã-Bretanha. Ehrlich e outros cientistas e ativistas que o apoiavam foram instantaneamente rotulados de "neo-malthusianos", o que não era exatamente um elogio, pois seus críticos queriam mostrar que, tal como supostamente fez Malthus, Ehrlich via a pobreza (e a degradação ambiental) como conseqüência do aumento da população carente. Sendo evolucionista, ou seja, um herdeiro intelectual de Charles Darwin, tal crítica não é infundada, uma vez que o próprio Darwin aponta o trabalho de Malthus como a matriz da idéia de "economia da natureza", o contexto original de sua teoria da evolução das espécies via seleção natural.

Em geral, os cientistas sociais ignoraram-no ou estigmatizaram-no. Em primeiro lugar, estranhavam que um biólogo aplicasse aos humanos um método próprio para estudar animais e plantas. Este é um exemplo claro do quanto esses sociólogos estavam tomados pelo já citado "paradigma da imunidade humana" às variáveis naturais - ou seja, a idéia de que os homens seriam a única espécie cujo crescimento exponencial não teria limites nem implicações sobre a natureza. Em segundo lugar, rejeitavam a perspectiva malthusiana de Ehrlich, estabelecendo-se firmemente no campo daqueles para quem o crescimento populacional não é um problema grave, ou sequer um problema. isso deriva de uma visão profundamente utilitarista sobre a natureza, que defende a expansão contínua da espécie humana para além de quaisquer considerações sobre a base de recursos naturais que sustentam a espécie.

De fato, havia um tom malthusiano em The population bomb se pensarmos nos dados sobre a pobreza com que Ehrlich lidava. No entanto, o autor afirmou que também as populações dos países ricos tinham crescido exponencialmente, ou seja, não os "inocentava" - detalhe importante que os críticos não sabem justamente porque não $\mathrm{O}$ leram devidamente. Ehrlich focalizava a tensão que considerava mais alarmante, qual seja, a coincidência de haver cada vez mais pessoas e menos comida nos países pobres; foi por esse motivo que se deteve no estudo desses países. Fundou um movimento/organização denominado ZPG (Zero Population Growth [Crescimento Populational Zero]), incentivando campanhas para conter o crescimento populacional e estimular o planejamento familiar, tanto em países ricos como pobres. ${ }^{6}$

Ehrlich logo incorporou parte das críticas recebidas. Em outro livro - The end of affluence, lançado em 1974, com a colaboração da sua esposa, Anne Ehrlich, deu o devido peso ao papel dos níveis elevados de consumo dos países mais ricos no quadro do esgotamento de recursos naturais. Embora menos numerosos e com crescimento populacional muito mais lento (no século XX) em comparação com o que ocorria em países subdesenvolvidos, esses países consumiam proporcionalmente muito mais recursos naturais e, por isso, tinham um maior peso na destruição ambiental em escala planetária. Esse tipo de "regra de três" se banalizou, aliás, na literatura ambientalista, principalmente na dos ambientalistas "sociais" ou partidários da "ecologia política", que muitas vezes 
pensam que um biólogo não possui a sensibilidade para perceber as nuanças que envolvem as questões ambientais - pensam assim porque não leram Ehrlich. Este autor passou a cruzar os dados e as taxas de crescimento populacional com os níveis médios de consumo. Em The end of affluence, os autores discutem, para além da análise de países subdesenvolvidos, indicações da insustentabilidade do moderno modelo industrial de países ricos, enfocando sua voracidade por recursos naturais.

Vale lembrar da crítica ao Brasil numa breve seção intitulada "O Brasil: o gigante adormecido que pode morrer em breve" (pp. 128-137), que se segue a outra seção - igualmente crítica - sobre o "sobre-desenvolvimento" japonês no período pós1945. Ehrlich critica o Brasil não apenas pelo crescimento populacional, mas também por sua adoção sôfrega de um modelo de crescimento acelerado, baseado em grandes unidades de produção e no consumo abundante de energia. Mais especificamente, a crítica recai sobre o que chamamos de "milagre brasileiro" da década de 1970, alvo de todo ambientalista que se preze. É curioso ver como esse texto breve e até superficial, bastante desconhecido entre os brasileiros, contém argumentos (certos ou equivocados) que hoje estão integralmente incorporados nas análises de neófitos do ambientalismo "social" ou "de esquerda" brasileiros - disparidades regionais do desenvolvimento, concentração de renda, expansão da soja e outras monoculturas, ocupação desordenada da fronteira amazônica, inadequação dos solos amazônicos para cultivos de grande escala, escalada da construção de estradas, deslocamento de populações indígenas, posição "pró-poluição" da delegação brasileira na Conferência de Estocolmo etc. Trata-se de uma agenda de temas sociais bastante respeitável para um "simples naturalista"...

Assim, para Ehrlich, o foco no crescimento populacional não foi um obstáculo para a construção de uma relação mais racional entre os seres humanos e os meios de suporte extraídos do mundo natural. Ainda baseado no conceito biológico de "capacidade de carga" do planeta, ele introduziu nesse segundo livro, como variáveis intervenientes, a moderna tecnologia de grande escala e os níveis médios diferenciados de consumo dos recursos naturais dos países ricos - e até de um país emergente como o Brasil.
Desde então o conceito biológico de "capacidade de carga" se inscreveu de modo indelével se bem que nem sempre explicitamente - na literatura científica e nos debates políticos e ideológicos sobre o meio ambiente. Muitos cientistas e ambientalistas "sociais" ainda o ignoram ou simplesmente o desconsideram. No entanto, o mais moderno e flexibilizado conceito de sustentabilidade, proposto pela Comissão Brundtland, nasceu da concepção de "capacidade de carga", buscando, além disso, resolver a mesma fração implícita nessa idéia. Ninguém mais se choca hoje em dia quando, por exemplo, um estudioso divide a oferta de água doce dos mananciais de uma bacia hidrográfica pelo número de consumidores e chega a uma cifra indicativa do nível alegadamente "sustentável" de consumo por habitante. Isso se tornou um procedimento tão imprescindível quanto banal.

A implicação mais ampla da reflexão de Ehrlich sobre o crescimento populacional é que a humanidade trilha um caminho insustentável, pois tende a consumir mais do que a natureza tem a seu dispor e mais do que a capacidade produtiva instalada pela sociedade humana consegue atender. Pode-se discordar dele, ou chamá-lo de catastrofista e neo-maltuhisiano, mas é preciso admitir que, no final das contas, Ehrlich não é tão "naturalista" assim...

\section{A extinção de espécies e a biodiversidade-} efeitos sobre os homens

Extinction: the causes and consequences of the disappearance of species (Ehrlich e Ehrlich, 1985 [1981]) contribuiu decisivamente para inserir na agenda ambiental global dois outros tópicos bastante correlacionados - a extinção de espécies e a proteção da biodiversidade. Novamente, tratase de um cientista natural analisando um problema natural que, por sua vez, se tornou também ambiental, ou seja, um problema situado na interface natureza-sociedade. É verdade que há décadas botânicos e zoólogos já lidavam com o problema de extinção de espécies (e da conseqüente perda de diversidade), advindo tanto de causas puramente naturais, como das atividades humanas. No entanto, os cientistas sociais só prestaram atenção nesse problema depois que um grupo de 
cientistas naturais sistematizou dados a esse respeito em escala planetária, estabelecendo correlações importantes entre extinção de espécies e atividades humanas - desmatamento, caça ou pesca indiscriminada, poluição, eliminação de habitats, expansão de fronteiras agrícolas etc. -; ressaltou, ainda, o valor da biodiversidade para o bem-estar dos humanos, discutindo sobre isso por muito tempo e incansavelmente. Ehrlich foi um dos líderes desse grupo.?

Focalizado, é evidente, em plantas e animais, no entanto, esse estudo sistematiza (principalmente no Capítulo 4) informações e análises sobre os benefícios que aqueles trazem para a humanidade, em termos de alimentos, remédios, materiais de construção, fontes de energia, controle biológico (de "pragas"), serviços ambientais etc. Basta ler os títulos de capítulos ou seções - por exemplo, "Benefícios econômicos diretos da preservação de espécies"; "Extinções e serviços ecossistêmicos"; "O comércio de animais selvagens"; "Energia e destruição de habitats"; "Reprodução em cativeiro"; "Geração e manutenção de solos"; "Desenho de reservas"; "Recuperação de ecossistemas"; "Regulação da oferta de água doce"; "Polinização" - para ver que se trata principalmente de um livro sobre como as atividades humanas influenciam a vida na natureza, de um lado, e como as plantas e os animais atuam em nosso benefício, de outro. É um precursor de muitas pesquisas, impulsionou carreiras científicas e desencadeou políticas de proteção de espécies. Três capítulos inteiros (8, 9 e 10), bem ao gosto do ativista Ehrlich, são dedicados ao "que estamos fazendo e o que podemos fazer", ressaltando leis, políticas e práticas relevantes que tiveram êxito em muitos países.

No Capítulo 3, o autor envereda por um campo mais propriamente filosófico, sistematizando razões "simbólicas" para não se extinguir animais e plantas - compaixão, estética, fascinação e até o seu "direito intrínseco à existência". Nesse aspecto Ehrlich, tal como fez Leopold quase trinta anos antes, com mais profundidade, tangencia a raiz de uma corrente do ambientalismo contemporâneo, a deep ecology, ou "ecologia profunda", que assume uma posição biocêntrica ou ecocêntrica. Em outras palavras, o "naturalista" Ehrlich mais uma vez extrapola seu nicho e trata de atividades produtivas, valores humanos, argumentos utilitaristas e filosóficos, áreas em que muitos cientistas sociais, engajados apenas recentemente na questão ambiental, acreditam-se pioneiros. ${ }^{8}$

\section{Esgotamento de recursos naturais - a dispensa planetária se esvazia}

Outro tema importante para a formação do campo do ambientalismo moderno é o do esgotamento da oferta de recursos naturais. Esse tema preocupou cientistas e governantes europeus de meados do século XX, porém por razões especificamente políticas, ou seja, o esgotamento de recursos como conseqüência dos bloqueios comerciais ocorridos nas duas grandes guerras mundiais, do fim do colonialismo e das ameaças ou práticas de boicotes durante a Guerra Fria. No entanto, foi apenas no âmbito da nascente preocupação ambiental global que a escassez passou a ser vinculada ao funcionamento "normal" da economia mundial, e não uma decorrência de guerras, boicotes etc.

A questão emergiu como problema ambiental pleno com a publicação de um livro que teve uma enorme divulgação e influência duradoura, intitulado The limits to growth (Meadows et al., 1978 [1972]), também conhecido informalmente como "Relatório do Clube de Roma". Foi traduzido para cerca de trinta línguas, em grandes tiragens e debatido durante anos em todo o mundo e todo tipo de fórum. Trata-se de um estudo coletivo, interdisciplinar e bastante inovador, realizado por um grupo de dezessete pesquisadores de alto nível, oriundos de pelo menos seis países e liderados por Dennis Meadows e Donella H. Meadows, do Massachusetts Institute of Technology (Estados Unidos) - peritos em teoria dos sistemas, informática, recursos naturais, poluição, agricultura, mineralogia, econometria, ciência política e administração.

Embora seu marido, Dennis Meadows, fosse o diretor do projeto e detivesse os direitos autorais do relatório que deu origem ao livro, foi a norteamericana Donella Meadows (1941-2001) quem emergiu como o porta-voz do grupo. Graduada em química com Ph. D. em biofísica, era também analista de sistemas; fez carreira no Massachussets Institute of Technology e no Dartmouth College, 
e, graças à repercussão do livro e ao fato de ter sido uma exímea debatedora e divulgadora das idéias ali propostas, tornou-se, por assim dizer, uma "cidadã do mundo".

Por anos a fio esse livro gerou polêmicas e desencadeou eventos, pautou o trabalho de outros cientistas, inspirou relatórios similares, tanto aliados como rivais, e influenciou a discussão de tratados internacionais e planos de desenvolvimento. Donella Meadows aproveitou esse movimento para criar o International Network of Resource Information Centers, também chamado de Grupo Balaton. Essa rede é uma espécie de think tank que reúne analistas de sistemas de cinqüenta países, comprometidos com o aumento da eficiência no manejo de recursos naturais, tendo em vista seu uso sustentável. Em 1992, ainda na esteira do impacto do livro lançado vinte anos antes, Donella Meadows lançou outro livro, que pode ser considerado uma atualização do primeiro: Beyond the limits (Meadows et al., 1992). Com efeito, quando muitos cientistas sociais começavam a se interessar pela questão ambiental, Meadows já estava dando continuidade àquele projeto ambiental fundador.

Em The limits to growth, o grupo de pesquisa do MIT discutiu cinco fatores como limitadores do crescimento econômico global: aumento da população, estagnação da produção agrícola (por causa da exaustão de solos apropriados), exaustão dos recursos naturais (principalmente petróleo e certos minérios), pressões da produção industrial crescente e poluição. Nenhum deles pode ser considerado um assunto exclusivamente "natural", pois todos têm causas e implicações sociais. Vale lembrar que, mesmo com a ausência de biólogos na equipe, continuavam em evidência temas, como crescimento populacional e "capacidade de carga" do planeta, tão caros aos biólogos.

Meadows e equipe usaram uma modelagem computadorizada, muito sofisticada para a época, para desenvolver cenários baseados em análise multifatorial e em correlações simples e múltiplas. Este é hoje um procedimento comum adotado por universidades, planejadores governamentais, grupos de pesquisa, consultores e empresas. Os modelos absorviam e processavam, segundo os diferentes cenários programados, grandes volu- mes de dados sobre a disponibilidade de recursos (solos agrícolas, minérios e fontes de energia), o consumo de recursos naturais e alimentos, o crescimento populacional, as cargas de poluição lançadas nas águas e no ar etc. Todos os cenários desenvolvidos (que incluíam mudanças "atenuantes", como a multiplicação hipotética de reservas de minérios ou o aumento da produtividade agrícola) indicavam fortes possibilidades de colapsos sociais, econômicos e ecológicos globais, advindos da fome, da exaustão de petróleo e de certos minérios cruciais para a vida industrial, da destruição de solos agrícolas e da contaminação do ambiente natural por substâncias tóxicas. Alguns ocorreriam dentro de poucas décadas, caso as atividades produtivas e a população continuassem a crescer no mesmo ritmo.

Para alguns o livro era uma profecia catastrófica e iminente, para outros, um diagnóstico alarmante, mas representou antes de tudo um modelo para realização de novos estudos. Contudo, foi duramente criticado por marxistas e estudiosos de outras linhagens, por nacionalistas e por cientistas do terceiro mundo. Eles o consideraram determinista, alarmista, insensível à capacidade humana de fazer adaptações políticas e sociais que pudessem evitar as catástrofes previstas. Creio que seja uma crítica injusta, pois a própria teoria dos sistemas (que orientou a equipe de Meadows) pressupõe a ocorrência de "retroalimentações positivas", com base em constatações, decisões e mudanças de comportamento capazes de reverter ou suavizar a crise de qualquer sistema.

Por causa de sua preocupação com o crescimento populacional, o livro também foi rotulado de "neomalthusiano", o que era previsível. A crítica de políticos e cientistas dos países subdesenvolvidos incidiu sobre o fato de eles o considerarem uma tentativa "imperial" dos países ricos de restringir o processo de desenvolvimento dos mais pobres, em nome da amenização dos impactos das atividades humanas sobre o ambiente natural em escala global. Cientistas sociais que também o criticaram ainda sucumbiam ao paradigma do "social pelo social" e reduziam a questão ambiental a mais um item das polaridades entre países ricos e pobres, mas ao menos começavam a prestar atenção à questão ambiental e aos dados necessários para aferir sua existência e mensurá-la. 
Independentemente de errar em quase todas as suas previsões - risco inerente à construção de cenários -, há dois méritos relevantes que não podem ser esquecidos: (1) a idéia de que a continuidade da espécie humana precisa ser debatida no contexto das limitações biofísicas do meio natural e (2) o impulso à realização de estudos similares, de caráter global, regional ou nacional, focalizados de forma abrangente nas relações entre os estoques de recursos naturais e as atividades humanas. Ou seja, Meadows e co-autores mantiveram em pauta o conceito de "capacidade de carga" como instrumento legítimo de pesquisa sobre problemas sociais e econômicos. Esses dois preceitos estão na linhagem ascendente direta do conceito de desenvolvimento sustentável.

\section{A "tragédia" dos recursos de propriedade comum - desafios à capacidade de organização social}

Outro texto de forte influência no campo do ambientalismo é um pequeno artigo intitulado "The tragedy of the commons", de Garrett James Hardin (1915-2003), publicado originalmente em 1968 na revista Science. Norte-americano, formado em zoologia e com Ph.D. em microbiologia, Hardin fez uma longa carreira universitária na University of California (Santa Barbara), onde se tornou professor emérito de ecologia humana. Era um perito em questões de dinâmica de populações, humanas ou não. Entre sua extensa obra 350 artigos e 27 livros - o artigo supracitado foi republicado em mais de cem coletâneas, obtendo grande repercussão no mundo inteiro e foi durante muitos anos o artigo científico mais lido, citado e debatido em todo o mundo. Em 2003, num tributo ao autor, a revista Science dedicou um número especial aos 35 anos de contínuos debates em torno do polêmico artigo originalmente divulgado em suas páginas. Hardin foi, portanto, mais um prestigiado cientista natural que formou a base para o debate ambiental contemporâneo.

Não só cientistas naturais, mas também economistas, sociólogos, antropólogos, cientistas políticos e psicólogos discutiram suas idéias. Assim como outros autores já citados, Hardin estimulou, de um lado, cientistas naturais a se ocuparem das dimen- sões sociais e políticas das questões ambientais e, de outro, desafiou sociólogos a abrir novas linhas de pesquisa, utilizando-se de seus instrumentais. Além disso, era engajado em organizações e causas sociais, como a legalização do aborto, a referida Zero Population Growth (fundada por Ehrlich) e o combate à imigração ilegal nos Estados Unidos.

Apesar de sua formação, a abordagem de Hardin nesse famoso artigo - que no Brasil é muito mais citado do que lido - era visceralmente cultural ou política, e não naturalista. Segundo ele, no uso de recursos naturais de propriedade comum, o interesse individual tende a prevalecer sobre o interesse coletivo se não houver regras eficazes de acesso e uso. Isto é, nesse caso a dinâmica do uso dos recursos é movida pela ambição de usufruí-los individualmente, em detrimento do interesse geral a curto ou a longo prazo. Segundo Hardin, o acesso não-regulamentado a uma área comum ou a um estoque de recursos naturais tende a facilitar um uso irracional e, eventualmente, gerar seu esgotamento, com prejuízo para todos, independentemente da intenção de cada usuário, que apenas procura maximizar seu ganho individual. Chamou isso de "tragédia dos recursos de propriedade comum".

O exemplo que usou no famoso artigo é simplório e, rigorosamente, contraditório à sua premissa, conforme apontado por sociólogos e antropólogos. Ele imaginou uma situação em que uma comunidade camponesa hipotética mantém uma área de pastagem comum que, no entanto, acaba sendo sobre-explorada pelo acúmulo de decisões individuais maximizantes - o aumento de animais no pasto para além do ecologicamente possível -, levando a uma eventual degradação deste. $O$ exemplo de fato não é dos mais felizes, pois a prevalência do interesse individual significa que as regras de uso comum são fracas ou inexistentes. Ou seja, a situação imaginada de uma propriedade comum deteriorada não previa regras socialmente acatadas. Além do mais, há o equívoco "etnográfico" de supor que nessa comunidade a pastagem seria de propriedade comum, mas os animais, propriedade individual. Isto é, cada dono de animais estaria submetido também a regras comunitárias referentes ao pastoreio, o que implica regras não apenas "deterioradas", mas de alcance limitado. 
No entanto, a concepção trágica inferida no texto não é invalidada pela fragilidade do exemplo. Hardin tinha por base o conceito biológico da "capacidade de carga"; ele associava, assim como Ehrlich, a "tragédia" ao crescimento populacional explosivo da humanidade, de recursos muito mais volumosos mas tão finitos quanto os de um pasto. No caso do exemplo, a comunidade camponesa entraria em colapso por causa da destruição dos recursos naturais que the davam suporte, alimentando seu rebanho.

O inevitável rotulamento de "neomalthusiano" foi a crítica menos contundente que Hardin recebeu. Em contrapartida, foi considerado um defensor da privatização desregrada dos recursos naturais. De fato, foi um crítico severo de muitos mecanismos estatais de controle sobre os recursos e simpatizante de algumas soluções de mercado. Curiosamente, no entanto, sua posição - geralmente surpreendente para críticos que nunca leram sua obra - era de que os recursos naturais só seriam usados racionalmente com a existência de regras de acesso acatadas e bem definidas, fossem elas públicas ou privadas.

A fé de Adam Smith de que a "mão invisível do mercado" levaria ao bem comum no domínio econômico e social não ecoa no pensamento ambiental de Hardin, que supunha precisamente o contrário, ou seja, decisões individuais, pulverizadas e desregradas, levariam ao esgotamento dos recursos naturais e, conseqüentemente, a um "mal comum".

O fato de Hardin ser cético quanto a certas regras governamentais ou coercitivas não significa que ele era contra todas as regras, ou a favor apenas de regras liberais. Na verdade, parte das "soluções" que ele propunha se baseavam no "altruísmo" (assunto ao qual se dedicou extensamente em outros textos), ou seja, uma postura ética em que cada indivíduo deveria se preocupar com as implicações de suas decisões sobre o bem-estar comum. Tal preocupação só ocorreria com a internalização de regras adequadas de comportamento que levassem em conta o próximo. Ainda assim, Hardin era cético quanto à eficácia do altruísmo para além de pequenos grupos sociais. Sustentava que este se diluiria em meio a rivalidades e egoísmos étnicos e nacionais das grandes e complexas sociedades modernas. Com certeza, Hardin, tal como Aldo Leopold, pensou a questão ambiental também no terreno da filosofia, da ética e dos fundamentos do comportamento humano.

As questões levantadas naquele pequeno artigo em torno da propriedade comum - ou, mais freqüentemente, da propriedade pública ineficaz dos recursos naturais em face do seu esgotamento, do crescimento populacional e das formas de ação coletiva apropriadas no sentido de aproveitá-los racionalmente estimularam cientistas sociais a construírem um campo de estudo novo e bastante relevante - Common Property Resources (CPR) -, que atraiu, entre outros, cientistas políticos, como Elinor Ostrom (ver Ostrom, 1990), e economistas, como Mancur Olson (ver Olson e Landsberg, 1973). Talvez devamos a Hardin a importante inovação conceitual de abordar de maneira sociopolítica os recursos naturais como bens públicos, isto é, como bens cuja disponibilidade depende de ação coletiva e de regras construídas por grupos sociais e pelo poder público. O resultado mais pragmático dessa idéia talvez tenha sido apresentar a necessidade da criação de regras de acesso e de uso dos estoques de recursos naturais de maneira teórica e conceitual, o que hoje é um consenso. Novamente, vemos um biólogo abordando um tema ambiental de fundo, com reflexões sobre o seu conteúdo social, econômico, cultural e político; nesse caso o autor chegou a estimular os cientistas sociais a desenvolverem abordagens mais inovadoras.

\section{A saúde do planeta e dos bumanos}

O inglês James E. Lovelock (1919) formouse em química e pós-graduou-se em medicina e biofísica. Ele próprio se define como um pesquisador independente, mas em diversos momentos de sua carreira esteve ligado à Oxford University e a outras universidades e institutos de pesquisa, como Yale e Harvard. É outro cientista que poderia ter-se dedicado apenas a uma carreira "naturalista", com grande sucesso e impacto. Inventou, em 1957, um aparelho conhecido como ECS (Electron Capture Detector), que permite analisar a composição química de misturas de gases (por meio da cromatografia), podendo identificar traços de gases muito rarefeitos de até uma parte por trilhão (ppt). Esse aparelho revolucionário 
ajudou na análise de muitos aspectos da atmosfera terrestre e também de outros planetas. Foi usado para identificar sinais de vida em outros planetas, quando Lovelock, a serviço da Nasa, na década de 1960, ajudou na concepção da sonda interplanetária Voyager.

Outra descoberta científica pioneira de Lovelock foi a do destino dos gases CFCs, produzidos sinteticamente em larga escala desde a década de 1930 e disseminados pelo mundo afora por sistemas de refrigeração. Inspirado em Rachel Carson, que mapeou a maneira pela qual o sintético DDT se espalhava pelos ecossistemas e organismos, Lovelock, no final da década de 1960, decidiu se empenhar em descobrir onde se estabeleciam esses gases sintéticos, cujos efeitos deletérios ainda eram insuspeitados. Em 1972, adaptou seu aparelho ECD e embarcou numa longa viagem de barco, de norte a sul do oceano Atlântico. Documentou, então, pela primeira vez concentrações significativas dos CFCs na atmosfera.? Isso desencadeou o que ele chamou de "guerra do ozônio", ou seja, o longo e complexo debate em torno da destruição da camada de ozônio pela ação dos CFCs liberados na atmosfera.

Esse debate, por sua vez, deu origem a um volume inédito de pesquisas sobre a atmosfera, suas mudanças e seus efeitos sobre o clima global. Lovelock fez outras descobertas importantes sobre a distribuição e os papéis biológicos e climáticos de outras substâncias (naturais e sintéticas), não apenas na atmosfera, mas também nos oceanos e na crosta terrestre. Dessa forma, esse cientista também participou dos primórdios da discussão sobre o tão conhecido atualmente "efeito estufa" - aquecimento planetário causado ou acelerado pelo aumento de concentrações de certos gases na atmosfera, e as conseqüências em termos de mudança climática. Vale lembrar que ao longo de sua carreira teve como principal colaboradora e co-autora de muitos textos a bióloga norte-americana Lynn Margulis.

Ainda em plena atividade, Lovelock é hoje um dos mais influentes cientistas e divulgadores das questões ambientais. Sua fama decorre principalmente dos livros Gaia: a new look at life on earth (1979) e The ages of gaia (1988). O primeiro apresenta uma "hipótese" ou a "teoria de Gaia"; o segundo responde a críticas, mostrando novas evi- dências e novas argumentações a respeito de sua teoria. Trata-se de uma forma singular de entender nosso planeta como um grande organismo vivo. A atmosfera, os oceanos, os continentes e todas as formas de vida formam, segundo Lovelock, um sistema complexo e ativo, capaz de agir e reagir a alterações ("naturais" ou induzidas pelos homens) e de restabelecer as condições necessárias para o prosseguimento e a evolução da própria vida.

Ele afirma que o princípio básico da "teoria de Gaia" lhe ocorreu quando se deu conta do caráter quimicamente "inerte" ou "entrópico" das atmosferas de outros planetas. Em contraste, a atmosfera da Terra, sua temperatura e a salinidade dos oceanos, entre outros aspectos, apresentam conteúdos dinâmicos e "altamente improváveis", mas ainda assim relativamente equilibrados e duráveis, revelando-se não-entrópicos. A explicação disso, para ele, é que esses compartimentos do planeta são, por assim dizer, "manipulados" pela vida para reproduzir as condições favoráveis a ela.

Apesar das críticas e contestações que apontam falhas como, por exemplo, certo teleologismo e uma implausível intencionalidade da vida em perpetuar a si mesma, a hipótese de Gaia ajudou muitos cientistas a contextualizar os problemas ambientais atuais em escalas de tempo mais amplas, em escalas espaciais globais e num abrangente esquema de auto-regulação por forças biogeofísicas que agem muito além da esfera e da capacidade de intervenção da cultura humana.

Em termos sociais ou filosóficos - a dimensão que nos interessa aqui -, a hipótese de Gaia tem contribuído para que muitos estudiosos considerem a humanidade uma variável tardia e periférica nos grandes processos de mudança e de manutenção da vida e, por conseqüência, nas questões ambientais. Lovelock entende que a humanidade gera, sim, ameaças à vida, mas sobretudo em suas manifestações "macro". Podemos extinguir espécies macro (mesmo não querendo fazê-lo); no entanto, somos incapazes de extinguir os microorganismos (mesmo que quiséssemos); estes são, na visão do autor, a base dos grandes processos mantenedores da vida. Assim, Lovelock também se preocupa com a sustentabilidade da vida, mas o faz a partir de um paradigma biogeofísico, no interior do qual a aventura humana é uma parte ínfima de processos avassaladoramente maiores e mais complexos. 
O pensamento de Lovelock, portanto, apresenta um aparente paradoxo: sua preocupação com a continuidade da vida no planeta convive com a visão de que o ativismo, o planejamento e o gerenciamento ambientais talvez não sejam tão eficazes quanto podemos imaginar para a manutenção da vida. Para aqueles convencidos de que a ação social pode "salvar o planeta", esse é um pecado imperdoável do autor. De fato, a visão decorrente da "teoria de Gaia" "apequena" a ação dos humanos no contexto de processos complexos e de longo prazo, nos quais não se pode interferir ou sua interferência é diminuta. O máximo que Lovelock considera que os homens podem fazer para ajudar a perpetuar a vida (e conservar o ambiente natural) é interromper atividades altamente destrutivas. Isso não significa que ele "libera" a humanidade para destruições "menores"; ao contrário, ele participa, como cientista e cidadão, de iniciativas favoráveis à conservação do meio ambiente. No entanto, duvida da eficácia de muitas iniciativas de grande escala anunciadas como "salvadoras" do planeta.

Por conta disso, muitos cientistas sociais e ambientalistas "sociais" hesitam em avaliar Lovelock. Se, de um lado, aprendem com a "teoria de Gaia" apreciando especialmente sua visão "organicista" que enfatiza o equilibrio dos grandes processos vitais e a capacidade da vida de lutar pela sua própria continuidade; de outro, preferem agir ou apoiar ações e atitudes que Lovelock considera fúteis, criticando-o por estimular o grande público a assumir uma atitude contemplativa em relação a atividades notoriamente deletérias à vida. Em meados de 2004, Lovelock decepcionou alguns de seus admiradores ao se manifestar publicamente em favor da expansão da energia nuclear, mas ele se justifica de forma previsível - considera a energia nuclear mais limpa e segura, uma forma menos impactante de produzir a energia necessária para movimentar as atividades humanas.

De qualquer maneira, temos também em Lovelock um cientista natural que discute temas novos e caros aos ativistas e sociólogos interessados na questão ambiental, se bem que de uma forma que curiosamente qualifica certas ações humanas como irrelevantes perante as grandes forças da natureza. Dos autores analisados neste artigo, é o que mais se aproxima do chamado "naturalismo", embora tenha conseguido mobilizar a atenção e a ação de milhões de pessoas, de governos nacionais e de organismos internacionais para muitos problemas naturais com implicações sociais. ${ }^{10}$

\section{Considerações finais}

Espero ter ao menos ilustrado a contento que a base das principais questões que hoje chamamos de ambientais está no trabalho árduo de estudiosos do campo das ciências naturais, assim como ter logrado alertar os cientistas sociais para o quanto ainda podem aprender com a leitura dessa literatura.

Além do seu pioneirismo propriamente "temático", tentei mostrar que o moderno conceito de sustentabilidade - dentro do qual trabalha a grande maioria dos cientistas sociais que atualmente se ocupam da questão ambiental, em qualquer de suas dimensões - tem raízes no conceito biológico de capacidade de carga, o qual foi largamente utilizado nas pesquisas ilustradas neste artigo. Com efeito, esses trabalhos foram também pioneiros em termos conceituais e metodológicos. Reitero, portanto, a necessidade desse alerta no sentido de aprimorar a pesquisa no contexto de concepções atuais que trabalham com o conceito "brundtlandiano" mais abrangente de sustentabilidade, e assim avançar o conhecimento.

É um fato relevante - nem sempre destacado no campo das ciências naturais - que países subdesenvolvidos consomem recursos e poluem muito menos do que países ricos, mas essa distinção não muda a substância da fração básica desenvolvida nos estudos de capacidade de carga. Essa constatação apenas pondera os componentes do denominador, mas a fração continua a ser instrumento fundamental da análise socioambiental, como afirmei no início deste artigo.

A sustentabilidade, versão revista e ampliada do conceito de capacidade de carga, complementa-se com a inclusão dos princípios e requisitos de eqüidade social e econômica (entre países e povos, e dentro de cada povo e cada país) e de solidariedade intergeracional. No entanto, esses dois últimos elementos são mais éticos ou normativos do que científicos. Além do mais, eles estão presentes 
na filosofia e nas ciências sociais do Ocidente há pelo menos dois séculos. Ou seja, o núcleo propriamente científico do moderno conceito de sustentabilidade tem raízes na biologia.

Quanto mais cedo os cientistas sociais entenderem e aceitarem isso, mais bem lidarão com o enorme legado criado por aqueles pesquisadores que, na verdade, "inventaram" a moderna questão ambiental. Com certeza, a cooperação direta e indireta com cientistas naturais vislumbra ganhos de conhecimento, uma vez que a interdisciplinaridade exigida para a análise científica da questão ambiental vai muito além de tertúlias entre disciplinas irmãs, como a antropologia, a sociologia e a ciência política. ${ }^{11}$

\section{Notas}

1 Exceções são os trabalhos do inglês E. F. Schumacher (1973) e do polonês-francês Ignacy Sachs (1986), dois economistas que abordaram questões ambientais de forma vigorosa, influente e criativa em momentos em que elas ainda estavam em fase de construção. Esses autores foram, ao menos, reconhecidos e valorizados quase imediatamente, ao contrário de um outro pioneiro, o sociólogo norte-americano W. Frederick Cottrell (1955), cuja obra inovadora padeceu décadas de esquecimento.

2 Para uma visão diferente, expressa por dois sociólogos rurais norte-americanos contemporâneos de Buttell, Dunlap e Catton, ver Field e Burch Jr. (1988).

3 Por falta de espaço, alguns cientistas naturais fundadores da questão ambiental serão apenas mencionados. Vale esclarecer que esta amostra das contribuições desses autores é enviesada, uma vez que inclui apenas autores que escreveram originalmente na língua inglesa. Esta seção se baseia quase exclusivamente nos escritos originais ou "primários" citados, de autoria desses cientistas. Não abordarei os numerosos textos de comentaristas, discípulos e críticos. No entanto, alguns dados biográficos e bibliográficos foram obtidos em sites acessados via pesquisas simples no browser Google, usando apenas os nomes dos autores. Alguns deles - como Meadows, Hardin e Lovelock - têm sites especificamente dedicados a eles.

4 Os subtítulos desta seção indicam as distintas questões ambientais que cada autor identificou e con- tribuiu para divulgar com publicações a respeito. Não devem ser entendidos, no entanto, como uma sugestão de que cada autor tratou apenas da questão à qual está referido neste texto, nem que tenha sido o único a tratar da mesma.

5 Há referências a um episódio - que não consegui confirmar - que indica o quão perigoso esse livro foi considerado: seus herdeiros (ela faleceu em 1964) teriam vendido os direitos autorais do recémlançado Silent Spring a uma indústria de pesticidas, que, assim, impediria novas edições do livro. Contudo, em diversas edições mais recentes, nada consta sobre isso. O livro vem sendo reeditado regularmente pelo menos desde a década de 1980 . Se alguma empresa tentou tirá-lo de circuito, fracassou.

6 Não entrei no mérito da questão de os autores aqui examinados serem ou não de "direita", como foram e são muitas vezes qualificados por diferentes leitores. Para a discussão aqui proposta, basta saber que eles foram, todos, renovadores ou mesmo iconoclastas em suas respectivas comunidades científicas. Além do mais, tais qualificativos ideológicos apresentam opções no mínimo esdrúxulas quando aplicados a certas questões. Defender o controle populacional seria uma visão de "direita", e o laissez-faire reprodutivo, seria de "esquerda"? Denunciar a formação de desertos seria uma postura de "direita" e, em contrapartida, fomentar sua expansão, poderia ser considerada de "esquerda"? Apontar a iminência do esgotamento de recursos naturais seria uma concepção de "direita", ao passo que esgotá-los seria de "esquerda"? Ou ainda, a defesa da biodiversidade poderia ser considerada uma visão de "direita", e sua destruição seria de "esquerda"?

7 Edward O. Wilson (zoólogo), em suas memórias, refere-se jocosamente a alguns membros desse grupo como a "máfia das florestas úmidas". O grupo era formado, , além dele mesmo, por Ehrlich (biólogo) e outros cinco cientistas naturais: Jared Diamond (médico e biólogo), Thomas Lovejoy (biólogo), Norman Myers (biólogo e perito em manejo de vida silvestre), Thomas Eisner (ecólogo) e Daniel Janzen (biólogo). Eles certamente ajudaram a introduzir na agenda ambiental não apenas a questão da extinção de espécies, mas a causa correlata da preservação das florestas tropicais (em virtude dos altos índices de biodiversidade), tema consideravelmente relevante para o desenvolvimento da consciência ambiental brasileira, por motivos óbvios. A esse respeito, ver Wilson (1994).

8 Chega a ser constrangedor a apropriação equivocada, por parte de cientistas sociais novatos na área 
de ambientalismo, de temas e termos relacionados à extinção de espécies e à proteção da biodiversidade . Em dois encontros recentes de estudiosos e ativistas do meio ambiente (um deles realizado no Brasil), ouvi sociólogos afirmarem publicamente que certos grupos sociais - indígenas, seringueiros e outras populações "tradicionais" da Amazônia protegem e mesmo enriquecem a biodiversidade, pois "criam espécies novas". Solicitados pelas platéias a identificarem que espécies seriam essas, os palestrantes citaram arroz, milho, cana-de-açúcar, laranja e manga, ou seja, espécies domesticadas, originárias de outras regiões, continentes ou biomas. A ânsia de defender as virtudes ambientalistas desses grupos se soma à ignorância sobre o que seja a criação de uma espécie, o que gera afirmações canhestras como essas, que fazem cair no ridículo as causas que pretendem defender.

9 Foi-lhe negado o apoio financeiro solicitado aos órgãos ingleses de fomento à pesquisa para a viagem. Os pareceristas a consideraram implausível e irrelevante. Lovelock financiou a viagem e a pesquisa que se seguiu a ela com recursos próprios. Isso mostra que as próprias instituições de pesquisa tinham resistência em apoiar estudos ambientais.

10 Não pude, no espaço restrito deste artigo, dar o merecimento devido a outros cientistas pioneiros ou "ícones" da questão ambiental. Apresento, pois, de forma breve autores também relevantes nesse sentido: Edward O. Wilson (1929), zoólogo, um dos principais codificadores das questões acerca da biodiversidade, da extinção de espécies e da proteção dos ecossistemas (inclusive florestas tropicais úmidas); Stephen J. Gould (1941-2002), paleontólogo, um dos renovadores do darwinismo que contribuiu muito para o melhor entendimento da extinção contemporânea de plantas e animais; Amory Lovins (1947), físico, que se notabilizou por discutir os aspectos ambientais, sociais, econômicos e políticos das diversas modalidades (soft e hard) de energia; Barry Commoner (1917), ecólogo, prolífico divulgador das dimensões políticas e tecnológicas das questões ambientais; Lester Brown (1940), agrônomo e economista agrícola, fundador do famoso Worldwatch Institute. No Brasil, merecem entrar em lista similar: Alberto José Sampaio (botânico), Frederico Carlos Hoehne (biólogo), Cândido de Mello Leitão (zoólogo), José Cândido de Melo Carvalho (veterinário), Luiz Emygdio de Mello Filho (botânico), João Murça Pires (agrônomo), Augusto Ruschi (biólogo), Ibsen de Gusmão Câmara, Paulo Moreira da Silva, José Luiz Bélart (oficiais da Marinha de Guerra), Wanderbilt Duarte de Barros (agrônomo), Alceo Magnanini (biólogo), Harald Edgard Strang (agrônomo), Paulo Nogueira Neto (biólogo), Adelmar Coimbra Filho (biólogo), Olivério Pinto (biólogo), Helmut Sick (biólogo), Maria Tereza Jorge Pádua (agrônoma), José Lutzemberger (agrônomo), Flávio Lewgoy (geneticista e químico) e Sebastião Pinheiro (agrônomo). Sobre esses pioneiros cientistas brasileiros envolvidos na questão ambiental, ver Franco (2002) e Urban (1998; 2001).

11 Não abordei aqui as questões relativas à "determinação genética" do comportamento humano e da aplicabilidade das leis da evolução e do mecanismo da seleção natural à cultura humana. Por serem muito mais complexas e polêmicas, ainda estão longe de atrair cientistas naturais, de um lado, e cientistas sociais, de outro, para um campo comum. Com efeito, essas questões vão além da criação de temas e de linhas de pesquisa, pois se encontram na raiz da própria identidade dessas ciências, mostrando a origem comum das ciências sociais com a biologia. Para quem se interessa pela interface entre a biologia e a sociologia, é um tema de grande relevância, no qual biólogos e sociólogos têm feito investimentos consideráveis. Edward O. Wilson defende desde a década de 1970 uma abordagem "dura" - a sociobiologia -, apresentada mais recentemente de forma um pouco mais "suave" (consilience), mas ainda assim bastante assertiva (cf. Wilson, 1975, 1978, 1998). Ele defende nada menos do que a "unificação" do saber científico sobre a cultura humana sob a liderança da biologia evolutiva. Para uma discussão mais ponderada - mesmo que próxima da de Wilson sobre a questão nature versus nurture (natureza versus cultura), ver Ehrlich (2002).

\section{BIBLIOGRAFIA}

ALLABY, Michael (ed.). (1998), A dictionary of ecology. 2. ed. Oxford, Oxford University Press.

BUTTEL, Frederic H. (1986), "Sociology and the environment: the winding road toward human ecology". International Social Science Journal, 109: 337-356.

CARSON, Rachel L. (1955 [1950]), The Sea around us. Revised edition. Nova York, Mentor Books [edição original: Oxford, Oxford University Press, 1950]. 
Ballantine.

(1962), Silent spring. Nova York, (1995 [1941]), Under the sea. Nova York, Mentor Books [edição original: Oxford, Oxford University Press, 1941].

CMMAD - Comissão Mundial de Meio Ambiente e Desenvolvimento. (1987), Nosso futuro comum. Rio de Janeiro, Editora da Fundação Getúlio Vargas.

COTTRELL, W. Frederick. (1955), Energy and society: the relation between energy, social changes and economic development. Nova York, McGraw-Hill.

DUNLAP, Riley E. \& CATTON, William R. (1979), "Environmental sociology". Annual Review of Sociology, 5: 243-273.

EHRLICH, Paul R. (1986 [1968]), The population bomb. Revised edition. Nova York, Random House.

(2002), Human natures: genes, cultures and the buman prospect. Nova York, Penguin.

EHRLICH, Paul R. \& EHRLICH, Anne. (1984 [1974]), The end of affluence. Nova York, Random House, 1984.

(1985 [1981]), Extinction: the causes and consequences if the disappearance of species. Nova York, Ballantine Books [edição original: Nova York, Random House, 1981].

FIELD, Donald R. \& BURCH JR., William R. (1988), Rural sociology and the environment. Middleton, Wisconsin, Social Ecology Press.

FRANCO, José Luiz de Andrade. (2002), Proteção à natureza e identidade nacional: 19301940. Tese de doutorado, Departamento de História da Universidade de Brasília.

HARDIN, Garrett. (1968), "The tragedy of the commons". Science, 162: 1243-1248.

LEOPOLD, Aldo. (1984 [1949]), A sand county almanac. Nova York, Ballantine Books [edição original: Oxford, Oxford University Press, 1949].

LOVELOCK, James E. (1979), Gaia: a new look at life on earth. Oxford, Oxford University Press.

LOVELOCK, James E. (1988), The ages of gaia. Nova York, EW. W. Norton.

MEADOWS, Donella et al. (1972), The limits to growth. Nova York, Universe Books [edição brasileira: Limites do crescimento. 2 ed. São Paulo, Perspectiva, 1978].

MEADOWS, Donella et al. (1992), Beyond the limits. White River Junction, Vermont, Chelsea Green Publishing Company.

OLSON, Mancur \& LANDSBERG, Hand H. (eds.). (1973), The no-growth society. Nova York, Norton.

OSTROM, Elinor. (1990), Governing the commons: the evolution of institutions for collective action. Cambridge, Cambridge University Press.

SACHS, Ignacy. (1986), Ecodesenvolvimento: crescer sem destruir. São Paulo, Vértice.

SCHUMACHER, E. F. (1973), Small is beautiful: economic as if people matterred. Londres, Blond \& Briggs.

SEARS, Paul B. (1988 [1935]), Deserts on the march. Washington, D.C., Island Press (Conservation Classics Series) [edição original: University of Oklahoma Press, 1935].

SILVA, Pedro Paulo de Lima et al. (2002), Dicionário brasileiro de ciências ambientais. 2 ed., revista e ampliada. Rio de Janeiro, Thex.

URBAN, Teresa. (1998), Saudade do Matão. Curitiba, Editora da Universidade Federal do Paraná.

. (2001), Missão (quase) impossível: aventuras e desventuras do movimento ambientalista no Brasil. São Paulo, Editora Peirópolis.

WILSON, Edward O. (1975), Sociobiology: the new synthesis. Cambridge, Harvard University Press.

(1978), On buman nature. Cambridge, Harvard University Press. 
(1994), Naturalist. Washington, Island Press.

(1998), Consilience: the unity of know-

ledge. Nova York, Alfred A. Knopf. 


\section{A PRIMAZIA DOS CIENTISTAS NATURAIS NA CONSTRUÇÃO DA AGENDA AMBIENTAL CONTEMPORÂNEA}

José Augusto Drummond

Palavras-chave: Questão ambiental; Poluição; Crescimento populacional; Recursos naturais; Desertificação; Extinção de espécies.

Este artigo discute as contribuições de sete cientistas naturais - Paul Sears, Aldo Leopold, Rachel Carson, Paul Ehrlich, Donella Meadows, Garrett Hardin e James Lovelock - na construção da agenda ambiental contemporânea. O autor sustenta que os cientistas sociais chegaram a ela de forma retardatária e, por vezes, parcialmente equivocada por se apegarem a uma tradição de explicar o "social apenas pelo social". Muitos cometeram ainda o erro de ignorar as contribuições daqueles pioneiros, com prejuízo para as suas próprias análises. Creio que seja imprescindível que pesquisadores do campo das ciências exatas e humanas dialoguem de forma mais intensa sobre os temas da agenda ambiental.

\section{NATURAL SCIENTISTS AS LEADERS IN THE CREATION OF THE CONTEMPORARY ENVIRONMENTAL AGENDA}

José Augusto Drummond

Keywords: Environmental issues; Pollution; Population growth; Natural resources; Desertification; Extinction of species.

The article discusses the contributions made by seven natural scientists - Paul Sears, Aldo Leopold, Rachel Carson, Paul Ehrlich, Donella Meadows, Garrett Hardin, and James Lovelock to the establishment of the contemporary environmental agenda. It argues that almost every major issue in this agenda was brought up and publicized originally by natural scientists. Social scientists interested in these issues were latecomers, mostly because they held on to the "human exemption paradigm." Sometimes they also ignore the contributions of their colleagues in the natural sciences, a flaw that affects negatively the quality of their own endeavors. The article proposes that social scientists and natural scientists should deepen their exchanges on environmental matters.

\section{LA PRIMAUTÉ DES SCIENTIFIQUES NATURELS DANS LA CONSTRUCTION DE L'AGENDA ENVIRONNEMENTAL CONTEMPORAIN}

José Augusto Drummond

Mots-clés: Environnement; Pollution; Croissance démographique; Ressources naturelles; Désertification; Extinction des espèces.

L'article aborde les contributions de sept chercheurs du domaine des sciences naturelles - Paul Sears, Aldo Leopold, Rachel Carson, Paul Ehrlich, Donella Meadows, Garrett Hardin et James Lovelock - à la construction de l'agenda environnemental contemporain. L'auteur défend que les scientifiques sociaux ont conçu cet agenda de façon retardataire et, parfois, partiellement inexacte, car ils se sont attachés à une tradition qui explique le social uniquement par le social. Nombreux sont ceux qui ont commis l'erreur d'ignorer les contributions de ces pionniers, au détriment de leurs propres analyses strictement sociales. Le texte propose que les chercheurs, dans les domaines des sciences sociales et des sciences naturelles, dialoguent de manière plus intensive sur les thèmes de l'agenda environnemental. 